\title{
Water loss detection in water distribution networks by artificial immune systems-based on model calibration
}

\section{Yapay bağışıklık sistemleri ile su dağıtım şebekelerindeki su kayıplarının model kalibrasyonuna bağlı olarak tespit edilmesi}

\author{
Miraç ERYIĞ́IT $1^{*}$ \\ 1Department of Environmental Engineering, Faculty of Engineering-Architecture, Abant Izzet Baysal University, Bolu, Turkey. \\ miraceryigit@hotmail.com
}

\begin{abstract}
This study aims at the development of an optimization model based on a model calibration, using Artificial Immune Systems (AIS) for quantifying and locating water losses in water distribution networks (WDNs). The modified Clonal Selection Algorithm (modified Clonalg), a class of AIS, was used as a heuristic optimization technique in the model. EPANET 2 was used in conjunction with the model. The model was applied to two-loop virtual WDN under steady-state conditions in order to test its performance in the detection of water losses in both pipes and nodes. The results showed that the model appeared to be promising in terms of the water loss detection in WDNs.
\end{abstract}

Keywords: Water loss detection, Leakage, Water distribution network, Model calibration, Artificial immune systems, Optimization

\section{Introduction}

Water is of vital importance for all living creatures due to being a life source. This also increases the economic value of water. In this regard, the detection of water losses comes into prominence to prevent them in water distribution networks (WDNs). Water losses in the WDNs consist of unauthorized water consumptions, meter inaccuracies, and leakages or bursts of pipes and nodes. Misiunas [1] and De Silva et al. [2] compiled the most commonly used leakage detection techniques in WDNs, which are Static Mass Balance [3]-[5], State Estimation [6]-[8], Transient Analysis [9]-[28], Acoustic Methods [29]-[45]. Within these techniques, various sensors, meters, monitoring systems and measurements (flow rate, pressure and temperature sensors detecting quasi-static signals, acoustic sensors detecting sound waves/noises, electro-magnetic sensors, infrared thermography, transmitters emitting radio frequencies, manometers, flow meters, SCADA, tracing substances so on.) are used and installed into WDNs. Therefore, the water loss detection is an expensive and difficult task. In order to facilitate the task, an optimization model based on a model calibration, using Artificial Immune Systems (AIS) was developed in this study. The model minimizes number of required field measurements used in a model calibration (pressures are not used) for detecting water losses in pipes and nodes of WDNs. The model was applied to two-loop virtual WDN under steady-state conditions in order to test its performance in the water loss detection. The results showed

\section{Öz}

Bu çalışmada, su dağıtım şebekelerindeki su kayıplarının miktarları ve yerlerinin tespit edilmesi için Yapay Bağısılklık Sistemleri (YBS) kullanılarak model kalibrasyonuna dayalı bir optimizasyon modelinin geliştirilmesi amaçlanmıştır. Modelde sezgisel optimizasyon tekniği olarak YBS' nin çeșitlerinden biri olan Modifiye edilmiș Klonal Seçim Algoritması kullanılmıştır. Model ile birlikte EPANET 2 simulatörü kullanılmıștır. Borularda ve düğüm noktalarındaki su kayıplarının tespit edilmesindeki performansını test etmek üzere model, sürekli (sabit) koșullar altında iki gözlü sanal bir su dağıtım sebekesine uygulanmıștır. Sonuçlar, su dağıtım şebekelerindeki su kayıplarının tespit edilmesi açısından modelin gelecek vadettiğini göstermiștir.

Anahtar kelimeler: Su kaybı tespiti, Sızma, Su dağıtım șebekesi, Model kalibrasyonu, Yapay bağışıklık sistemleri, Optimizasyon

that the model can detect both locations and amounts of water losses in the WDN.

\section{Material and method}

\subsection{Methodology and formulation}

Model calibration is the process of minimizing the discrepancy between the model predictions and field observations of pressures and flows to determine the physical and operational characteristics of an existing system. These characteristics consist of model parameters such as pipe roughness, nodal demand, operation status of pipes, pumps, valves and tanks [46]-[50]. Wu et.al. [48] defined model calibration as an implicit nonlinear optimization problem and used it for determining pipe roughness coefficients via Genetic Algoritm (GA). Model calibration is also utilized for detecting water losses or leaks in WDNs. Wu and Sage [49] presented an optimization-based approach using GA for simultaneously quantifying and locating water losses via the process of hydraulic model calibration. Prasad [51] proposed a model using Clonal Selection Algorithm (Clonalg) to determine model parameters including nodal demands, pipe roughness values, valve closures, pump controls and valve settings. Nasirian et al. [52] studied leak detection based on calibration in WDNs, and introduced a novel optimization method combining with GA to calibration and leakage detection in networks. In order to obtain model parameters in WDNs, model calibration process is optimized by minimizing the discrepancy between the model predicted and the field observed values of junction pressures and pipe flows under boundary conditions such as tank levels, control valve 
setting and pump speeds. The objective function $(f)$ is defined as follows [48]:

$$
\text { minimize } \frac{\sum_{n h=1}^{N H} w_{n h}\left(\frac{H s i m_{n h}-H o b s_{n h}}{H_{p n t}}\right)^{2}+\sum_{n f=1}^{N F} w_{n f}\left(\frac{F s i m_{n f}-F o b s_{n f}}{F_{p n t}}\right)^{2}}{N H+N F}
$$

where $H_{o b s} n$ is $n h$-th observed pressure, $H_{s i m} n$ is $n h$-th simulated pressure, Fobs $n f$ is $n f$-th observed flow rate, Fsim $n f$ is $n f$-th simulated flow rate, Hpnt notes the hydraulic head per fitness point while Fpnt is the flow per fitness point, $N H$ is the number of observed pressures, and $N F$ is the number of observed pipe flows, $w_{n h}$ and $w_{n f}$ are the weighting factors. Instead of Equation (1), Equation (2) was derived for detecting water losses in the WDN in this study:

$$
\text { minimize } \frac{\sum_{n d=1}^{N D}\left(D_{s i m}-D_{n d} o b s_{n d}\right)^{2}+\sum_{n f=1}^{N F}\left(F \operatorname{sim}_{n f}-F o b s_{n f}\right)^{2}}{N D+N F}
$$

where Dobsnd is the $n d$-th observed junction (nodal) demand, $D_{\text {sim }}$ is the $n d$-th model simulated junction demand. In this study, unauthorized water consumptions in nodes, and leakages in pipes were considered as water losses in WDNs. As applied by [8], all leakages in pipes were assumed as pseudo nodes and simulated as nodal demands. Unauthorized consumptions were added as a demand by demand multipliers to base demands in nodes [49]. In the detection of water losses, the objective function is minimized by considering the following constraints:

The equation of continuity has to be met for each node:

$$
\sum Q_{\text {inf }}-\sum Q_{\text {outf }}=Q_{e f}
$$

where Qinf and Qoutf are inflow and outflow of a node, $Q_{e f}$ is the external inflow or water demand at a node. The minimum pressure required for each node is formulated as the following:

$$
H_{j} \geq H_{j}^{\min } \quad j=1, \ldots, M
$$

where $\mathrm{H}_{\mathrm{j}}$ is the pressure head at node $\mathrm{j}, \mathrm{H}_{\mathrm{j}}$ min is a minimum required pressure head at node $\mathrm{j}, \mathrm{M}$ is the number of nodes in WDN. The penalty function was defined in case of violating the constraints as follows:

$$
\text { If } H_{j}<H_{j}^{\min } \rightarrow\left|H_{j}\right|+f \quad j=1, \ldots, M
$$

In this study, $\mathrm{H}_{\mathrm{j}}$ min was assigned as zero so that negative pressures not occur in the nodes. EPANET 2 was used for hydraulic computations [53]. The modified Clonalg was utilized for minimizing the objective function above. Eryigit [54] defined the modified Clonalg for optimization problems as follows:

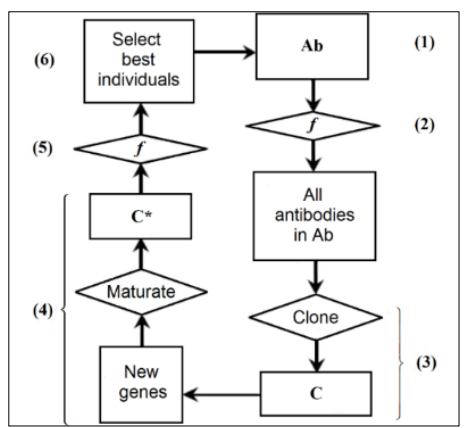

Figure 1: Diagram of the modified Clonalg. where $\mathrm{Ab}$ is an antibody population randomly generated, $f$ is an antigenic affinity corresponding to the objective function of a given antibody, $C$ is a set of antibodies cloned, $C^{*}$ is a set of matured (mutated) antibodies after the cloning process.

Description of $\mathrm{Ab}$ :

$$
\overbrace{\left[\begin{array}{cccccc}
A b_{1}=x_{I 1} & \cdots & x_{1 j} & \cdots & x_{\text {Ind }} \\
\vdots & \vdots & & & & \vdots \\
A b_{i}=x_{i 1} & & \ddots & & x_{\text {ind }} \\
\vdots & \vdots & & & & \vdots \\
A b_{N_{A b}}=x_{N_{A b} l} & \cdots & x_{N_{A b} j} & \cdots & x_{N_{A b} n d}
\end{array}\right]}^{A b} \rightarrow \overbrace{\left[\begin{array}{c}
f_{l} \\
\vdots \\
f_{i} \\
\vdots \\
f_{N_{A b}}
\end{array}\right]}^{f}
$$

where $N_{A b}$ is the total number of $\mathrm{Ab}, x_{i j}$ is a gene of $A b_{i}$ (decision variable of $f$ ), nd is the number of genes. In the study, $x_{i j}$ corresponds to the nodal demand. The modified .Clonalg was coded in Matlab 2012a software in conjuction with EPANET 2.

\subsection{Sample two-loop WDN}

The network contains seven actual nodes including nodes 1-6, and a reservoir, eight pipes with two loops, and is fed by the gravity from a 75-m-head reservoir. Nodes 7-13 are pseudo nodes representing leakages in pipes. Also, unauthorized water consumptions were added to base demands in nodes 1-6 as water losses. Data and layouts of Two-loop WDN are given in Table 1, Table 2, and illustrated in Figure 2, and Figure 3, respectively.

As it is seen in Figure 2 and 3, leakages in pipes 1, 2 and 5 (pseudo nodes 9, 7 and 8, respectively) can be calculated by eq. (3) with observed data (For example, pseudo node $9=120.68$ $\mathrm{l} / \mathrm{s}-(44 \mathrm{l} / \mathrm{s}+72.68 \mathrm{l} / \mathrm{s}))$ while leakages in pipes 3, 4, 6 and 7 (pseudo nodes 10,12, 11 and 13 , respectively) cannot. Although there is no leakage in pipe 3, it was assumed as a pseudo node (node 10) due to it's a leak candidate.

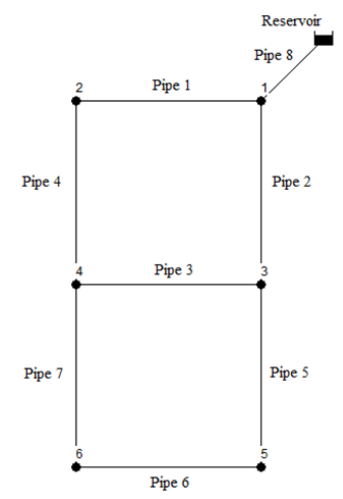

Figure 2: Layout of Twoloop WDN.

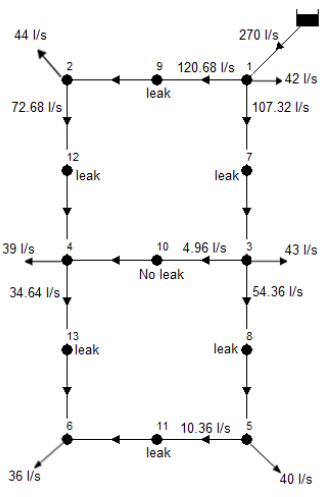

Figure 3: Operating layout of two-loop WDN.

\section{Results}

The optimization model was run 20 times for Two-loop network. Random seed was carried out while constituting an initial set in each run. A PC with Intel I5 Core 2.5 Ghz (3.1 Ghz with Turbo Boost) and Matlab 2012a were used for the analysis. The results of the model were given in Table 3 and Table 4 . 
Table 1: Data of Two-loop WDN.

\begin{tabular}{ccc|cccc}
\hline Node & Elevation $(\mathrm{m})$ & Base demand $(\mathrm{l} / \mathrm{s})$ & Pipe & Length $(\mathrm{m})$ & Diameter $(\mathrm{mm})$ & $\mathrm{C}$ \\
\hline Reservoir & 75 & - & 1 & 500 & 300 & 300 \\
1 & 0 & 40 & 2 & 500 & 100 \\
2 & 0 & 40 & 3 & 500 & 100 \\
3 & 0 & 40 & 5 & 500 & 100 \\
4 & 0 & 35 & 6 & 500 & 100 \\
5 & 0 & 35 & 7 & 500 & 100 & 100 \\
6 & 0 & 30 & 8 & 1000 & 100 & 100 \\
& & & & & 500 & 100 \\
\hline
\end{tabular}

Table 2: Operating data of two-loop WDN.

\begin{tabular}{ccc|ccc}
\hline Node & $\begin{array}{c}\text { Observed } \\
\text { Demand }(\mathrm{l} / \mathrm{s})\end{array}$ & $\begin{array}{c}\text { Water loss } \\
\text { in node }(\mathrm{l} / \mathrm{s})\end{array}$ & Pipe & $\begin{array}{c}\text { *Observed } \\
\text { flow rate }(\mathrm{l} / \mathrm{s})\end{array}$ & $\begin{array}{c}\text { Leakage } \\
\text { in pipe }(\mathrm{l} / \mathrm{s})\end{array}$ \\
\hline Reservoir & - & - & 1 & 120.68 & 4 \\
1 & 42 & 2 & 2 & 107.32 & 5 \\
2 & 44 & 4 & 3 & 72.68 & 0 \\
3 & 43 & 3 & 5 & 54.36 & 4 \\
4 & 39 & 4 & 6 & 10.36 & 4 \\
5 & 40 & 5 & 7 & 34.64 & 5 \\
\end{tabular}

*All observed flow rates were assumed to be only measured at initial points of pipes in the WDN.

Table 3: Parameters and performance of the modified Clonalg for the objective function

\begin{tabular}{ccccccccc}
\hline $\mathrm{NAb}$ & $\beta$ & $\rho$ & Probability rate & $\begin{array}{c}\text { Iteration } \\
\text { Number }\end{array}$ & $\begin{array}{c}\text { Min.f } \\
(\mathrm{l} / \mathrm{s})\end{array}$ & $\begin{array}{c}\text { Max.f } \\
(\mathrm{l} / \mathrm{s})\end{array}$ & $\begin{array}{c}\text { Avg. f } \\
(\mathrm{l} / \mathrm{s})\end{array}$ & $\begin{array}{c}\text { Avg. run time } \\
(\mathrm{min})\end{array}$ \\
\hline 30 & 1 & 8 & 0.1 & 5000 & $1.29 \times 10^{-5}$ & $11.5 \times 10^{-5}$ & $4.69 \times 10^{-5}$ & 40.9 \\
\hline
\end{tabular}

$\beta$ : Multiplying coefficient for the cloning. $\rho$ : Decay coefficient.

Table 4: Comparison of actual and predicted water losses in nodes and pipes.

\begin{tabular}{ccccccc}
\hline Node & $\begin{array}{c}\text { Avg. Predicted Demand } \\
(\mathrm{l} / \mathrm{s})\end{array}$ & $\begin{array}{c}\text { Observed } \\
\text { Demand } \\
(\mathrm{l} / \mathrm{s})\end{array}$ & $\begin{array}{c}\text { Avg. } \\
\text { Pressure* } \\
(\mathrm{m})\end{array}$ & $\begin{array}{c}\text { Pipe } \\
\text { Avg. Predicted } \\
\text { Leakage* } \\
(\mathrm{l} / \mathrm{s})\end{array}$ & $\begin{array}{c}\text { Leakage } \\
(\mathrm{l} / \mathrm{s})\end{array}$ \\
\hline 1 & 42.0012 & 42 & 69.54 & 1 & 4.006 & 4 \\
2 & 43.9990 & 44 & 62.37 & 2 & 4.977 & 5 \\
3 & 43.0027 & 43 & 63.84 & 3 & 0.032 & 0 \\
4 & 39.0027 & 39 & 59.62 & 4 & 3.972 & 4 \\
5 & 39.9999 & 40 & 52.47 & 5 & 4.005 & 4 \\
6 & 36.0003 & 36 & 40.85 & 6 & 3.995 & 5 \\
\hline
\end{tabular}

*Average of 20 runs.

\section{Conclusions}

The model can detect both locations and amounts of water losses in nodes and pipes of the WDN without using observed pressure data (see Equation (1)). Also, although there are four leakages (in pipes 3, 4, 6 and 7) in the WDN, which cannot be calculated by Equation (3) with observed data, they were detected successfully. These demonstrate that the model minimizes number of required field measurements used in a model calibration (pressures are not used) for detecting water losses in pipes and nodes of WDNs. The results showed that the model seems to be substantially successful and feasible for the water loss detection in WDNs. In next studies, a performance of the model should be tested for different WDNs.

\section{References}

[1] Misiunas D. "Burst Detection and Location in Pipelines and Pipe Networks with application in water distribution networks". Department of Industrial Electrical Engineering and Automation, Lund University, Lund, Sweden, 2003.

[2] De Silva D, Mashford J, Burn S. "Computer Aided Leak Location and Sizing in Pipe Networks". Urban Water Security Research Alliance, City East, Australia, 17 (2nd Ed.), 2011.

[3] Mounce S, Day A, Wood, A, Khan, A, Widdop, P, Machell J. "A neural network approach to burst detection". $1^{\text {st }}$ IWA Conference on Instrumentation, Control and Automation (ICA2001), Malmö, Sweden, 2001. 
[4] Khan A, Widdop P, Day A, Wood A, Mounce S, Machell J. "Low-cost failure sensor design and development for water pipeline distribution systems". Water Science and Technology, 45(4-5), 207-216, 2002.

[5] Mounce. S, Khan A, Wood A, Day A, Widdop P, Machell J. "Sensor-fusion of hydraulic data for burst detection and location in a treated water distribution systems". Information Fusion, 4, 217-119, 2003.

[6] Tao L, Wang C. "State estimation of output-decoupled complex system with application to fluid pipeline". IEEE Transactions on Industrial Electronics, 35(3), 469-475, 1988.

[7] Andersen J, Powell R. "Implicit state-estimation technique for water network monitoring". Urban Water, 2, 123-130, 2000.

[8] Poulakis Z, Valougeorgis D, Papadimitriou C. "Leakage Detection in Water Pipe Networks Using a Bayesian Probabilistic Framework". Probabilistic Engineering Mechanics, 18 (4), 315-327, 2003.

[9] Pudar RS, Liggett JA. "Leaks in Pipe Networks". Journal of Hydraulic Engineering-ASCE, 118(7), 1031-1046, 1992.

[10] Liggett J, Chen L. "Inverse transient analysis in pipe networks". Journal of Hydraulic Engineering-ASCE, 120(8), 934-955, 1994.

[11] Jönsson L. "Hydraulic transients as a monitoring device". Department of Water Resources Engineering, University of Lund, Lund, Sweden, 1995.

[12] Silva R, Buiatta C, Cruz S, Pereira J. "Pressure wave behaviour and leak detection in pipe-lines". Computers in Chemical Engineering, 20, 491-496, 1996.

[13] Brunone B. "Transient test-based technique for leak detection in outfall pipes". Journal of Water Resources Planning and Management-ASCE, 125(5), 302-306, 1999.

[14] Nash G, Karney B. "Efficient inverse transient analysis in series pipe systems". Journal of Hydraulic EngineeringASCE, 125(7), 761-764, 1999.

[15] Vitkovsky JP, Simpson AR, Lambert MF. "Leak detection and calibration using transients and genetic algorithms". Journal of Water Resources Planning Management, 126(4), 262-265, 2000.

[16] Brunone B, Ferrante M. "Detecting leaks in pressurised pipes by means of transients". Journal of Hydraulic Research, IAHR, 39(5), 539-547, 2001.

[17] Jönsson L. "Interaction of a hydraulic transient with a leak in a pipe flow". 14th Australasian Fluid Mechanics Conference, Adelaide University, Adelaide, Australia, 2001.

[18] Mpesha W, Gassman SL, Chaudry MH. "Leak detection in pipes by frequency response method". Journal of Hydraulic Engineering, 127(2), 134-147, 2001.

[19] Wang X, Lambert M, Simpson A, Liggett J, Vítkovský J. "Leak detection in pipeline systems using the damping of fluid transients". Journal of Hydraulic Engineering-ASCE, 128(7), 697-711, 2002.

[20] Ferrante M, Brunone B. "Pipe system diagnosis and leak detection by unsteady-state tests, 1 . Harmonic analysis". Advances in Water Resources, 26, 95-105, 2003.

[21] Kapelan Z, Savic D, Walters GA, Covas D, Graham IN, Maksimović Č. "An assessment of the application of inverse transient analysis for leak detection: Part ITheoretical considerations". Advances in Water Supply Management, 71-78, 2003.
[22] Covas D, Ramos H, Graham N, Maksimovic C. "Application of hydraulic transients for leak detection in water supply systems". Water Science. and Technology: Water Supply, 4(5), 365-374, 2004.

[23] Savic D, Lambert A, Kapelan Z. "Water losses management and leakage detection techniques for water distribution systems". Water and sewerage Journal, 2, 25-27, 2005.

[24] Lee PJ, Lambert MF, Simpson AR, Vitkovsky JP, Liggett J. "Experimental verification of the frequency response method for pipeline leak detection". Journal of Hydraulic Research. 44(5), 693-707, 2006.

[25] Lee PJ, Vitkovsky JP, Lambert MF, "Simpson AR, Liggett J. Leak location in pipelines using the impulse response function". Journal of Hydraulic Research, 45(5), 643-652, 2007.

[26] Hu J, Zhang L, Wang Z, Liang W. "Application of an improved ISODATA method to pipeline leak detection". Petroleum Science, 4(2), 97-104, 2007.

[27] Vitkovsky JP, Lambert M, Simpson A, Liggett JA. "Experimental observation and analysis of inverse transients for pipeline leak detection". Journal of Water Resources Planning and Management, 519-530, 2007.

[28] Sattar AM, Chaudhry MH. "Leak detection in pipelines by frequency response method". Journal of Hydraulic Research, 46(1), 138-151, 2008.

[29] Shaw-Cole E. "Methods of leak detection: an overview". Journal of AWWA, 71(2), 73-75, 1979.

[30] Grunwell D, Ratcliffe B. "Location of underground leaks using the leak noise correlator". Water Research Centre Publication, UK, 37, 1981.

[31] Fuchs HV, Riehle R. "Ten years of experience with leak detection by acoustic signal analysis". Applied Acoustics. 33(1), 1-19, 1991.

[32] Seaford H. "Acoustic leak detection through advanced signal-processing technology". Noise and Vibration Worldwide, 25(5), 17-18, 1994.

[33] Hunaidi O, Chu WT. "Acoustical Characteristics of Leak Signals in Plastic Water Distribution Pipes". Applied Acoustics, 58, 235-254, 1999.

[34] Smith LA, Fields KA, Chen ASC, Tafuri AN. "Leak and break detection and repair for drinking water systems". Battelle Press, Columbus, Ohio, USA, 2000.

[35] Tafuri AN. "Locating leaks with acoustic technology". Journal of AWWA, 92(7), 57-66, 2000.

[36] Bond A, Rees B. "Development of on-line inspection systems for Water Mains Proceeds". 4th International Conference of Water Pipeline Systems, 151-160, 2001.

[37] Fantozzi M, Fontana E. "Acoustic emission techniques: the optimum solution for leakage detection and location in water pipelines". The Journal of The British Institute of Non- Destructive Testing, 43(2), 105-107, 2001.

[38] McNulty JG. "An acoustic-based system for detecting, locating and sizing leaks in water pipelines, Proceeds". 4th Internarional Conference Water Pipeline Systems, 217-225, 2001.

[39] Wang X, Lambert M, Simpson A, Vítkovski J. "Leak detection in pipelines and pipe networks: a review". 6th Conference on Hydraulics in Civil Engineering, I.E, Hobart, Australia, 391-400, 2001.

[40] Long R, Cawley P, Lowe M. "Accoustic wave propagation in buried iron water pipe, Proceeds". Royal Society of London Series-A mathematical, physical and engineering sciences, 459, 2749-2770, 2003. 
[41] Pilcher R. "Leak detection practices and techniques: a practical approach". Water, 21, 44-45, 2003.

[42] Lockwood A, Murray T, Stuart G, Scudder L. "Locating leaks from water supply pipes using the passive acoustic method". Journal of Water Supply: Research and Technology-Aqua, 54 (8), 519-530, 2005.

[43] Brennan MJ, Joseph PF, Muggleton JM, Gao Y. "Use of acoustic methods to detect water leaks in buried plastic water pipes". Water and Sewage Journal, 1, 11-13, 2006.

[44] Kurtz DW. "Developments in a Free-Swimming Acoustic Leak Detection System For Water Transmission Pipelines, Proceed". Pipelines, ASCE, Chicago, USA, 2006.

[45] Fletcher R. "Smartball-A new approach in pipeline leak detection". Proceedings International Pipeline Conference IPC2008, Calgary, Canada, 2008.

[46] De Schaetzen WBF, Walters GA, Savic DA. "Optimal sampling design for model calibration using shortest path, genetic and entropy algorithms". Urban Water Journal, 2(2), 141-152, 2000.

[47] Walski TM. "Understanding the adjustments for water distribution system model calibration". Journal of Indian Water Works Association, 151-157, 2001.

[48] Wu ZY, Walski T, Mankowski R, Cook J, Tryby M, Herrin G. "Calibrating Water Distribution Model Via Genetic Algorithms". Proceedings of the AWWA IMTech Conference, Kansas City, USA, 16-19 April 2002.
[49] Wu ZY, Sage P. "Water loss detection via genetic algorithm optimization-based model calibration". ASCE 8th Annual International Symposium on Water Distribution Systems Analysis, Cincinnati, Ohio, USA, 27-30 August, 2006.

[50] Savic D, Kapelan Z, Jonkergouw PMR. "Quo vadis water distribution model calibration?" Urban Water Journal, 6(1), 3-22, 2009.

[51] Prasad TD. "A Clonal Selection Algorithm for the C-Town Network Calibration". ASCE Water Distribution Systems Analysis, WDSA2010, Tucson, AZ, USA, 12-15 September, 2010.

[52] Nasirian A, Maghrebi MF, Yazdani S. "Leakage Detection in Water Distribution Network Based on a New Heuristic Genetic Algorithm Model". Journal of Water Resource and Protection, 5, 294-303, 2013.

[53] Rossman L. "EPANET 2 Users Manual, Technical Report EPA/600/R-00/057". Water Supply and Water Resources Division, National Risk Management Research Laboratory, U.S., Environmental Protection Agency, Cincinnati, OH, USA, 2000.

[54] Eryigit M. "Cost optimization of water distribution networks by using artificial immune systems". Journal of Water Supply: Research and Technology-AQUA, 64(1), 47-63, 2015. 